University of New Hampshire

University of New Hampshire Scholars' Repository

\title{
$9-2015$
}

\section{Wearing Memories: Clothing and the Global Lives of Mourning in Swaziland}

\author{
Casey Golomski \\ University of New Hampshire, Durham, casey.golomski@unh.edu
}

Follow this and additional works at: https://scholars.unh.edu/anth_facpub

Part of the African Languages and Societies Commons, Christianity Commons, Comparative Psychology Commons, Fashion Design Commons, Missions and World Christianity Commons, Personality and Social Contexts Commons, Social and Cultural Anthropology Commons, Social Psychology Commons, Transpersonal Psychology Commons, and the Women's Studies Commons

\section{Comments}

This is an Author's Original Manuscript of an article published by Taylor \& Francis in Material Religion in 2015, available online: https://dx.doi.org/10.1080/17432200.2015.1082719

\section{Recommended Citation}

Golomski, Casey, "Wearing Memories: Clothing and the Global Lives of Mourning in Swaziland" (2015). Material Religion. 13.

https://scholars.unh.edu/anth_facpub/13

This Article is brought to you for free and open access by the Anthropology at University of New Hampshire Scholars' Repository. It has been accepted for inclusion in Anthropology Scholarship by an authorized administrator of University of New Hampshire Scholars' Repository. For more information, please contact Scholarly.Communication@unh.edu. 


\section{PUBLICATION}

Material Religion: Journal of Art, Objects and Belief, volume 11, issue 3 (September, 2015) 1

TITLE

Wearing Memories: Clothing and the Global Lives of Mourning in Swaziland

\section{AUTHOR NAME and BIO}

Casey Golomski is a University Research Council Postdoctoral Fellow at the University of the Witwatersrand in South Africa, and a Lecturer in Anthropology at the University of Massachusetts Boston. His research in Swaziland and South Africa centers on life cycle rites, religion, healing and healthcare, and families through attention to concepts of culture and value. His work has appeared in Johannesburg Salon, African Journal of AIDS Research, and American Ethnologist.

ABSTRACT: This article situates a cultural phenomenon of women's memory work through clothing in Swaziland. It explores clothing as both action and object of everyday, personalized practice that constitutes psychosocial wellbeing and material proximities between the living and the dead, namely, in how clothing of the deceased is privately possessed and ritually manipulated by the bereaved. While human and spiritual self-other relations are produced through clothing and its material efficacy, current global ideologies of immaterial mortuary ritual associated with Pentecostalism have emerged as contraries to this local, intersubjective grief work. This article describes how such contrarian ideologies paper over existing global aspects of peoples' entangled relations with the dead - in three biographies of women and their objects - thus showing that 
memory work is not limited to peoples, goods, and ideas that flow between nations and expanding notions of the global and gendered practices of personhood.

\section{KEYWORDS}

Memory, mourning, clothing, women, intersubjectivity, Pentecostalism, global, Swaziland

\section{MAIN TEXT \\ INTRODUCTION}

Zee Krystal, a street-wise woman from Manzini, described to me how her mother and mother's sisters suffered a break down after their aunt's death. The aunt went to the Netherlands and passed away, leaving a house full of her possessions in the Swaziland countryside. There was a lot of furniture left, including her large hope chest. South African photographer Zwelethu Mthethwa's 2012 "Hope Chest" series depicts the value of this furniture and storage item as a marital gift for Zulu women, an object constitutive of a woman's personhood across her life

course. ${ }^{2}$ What is stored inside, however, illustrates how embodied and intersubjective dimensions of this personhood are produced. Zee Krystal explained how the women went to assess the property and opened it after finding it behind an old rocking chair. "They pulled out all her clothes, making memories and crying," she said. "For Swazi, it's all about the clothes."

How do women "make memories" through clothing, and what is clothing "all about" in this particular historical moment? How does the transnational dimension of the aunt's death figure into the work of memory, and what does it portend for a relationship between mourning and globalization? This article considers these questions in an analysis of clothing in personal acts of memorialization, and the ways in which the global is implicated in the production of 
personhood and what is valuable. It locates this phenomenon of memory work as related to, but going beyond pervasive social conventions of adorning mourning gowns. It foregrounds the intersubjective dimensions of women's personal use of dead persons' clothing to show how these local practices ultimately implicate global flows of ideas, objects and people.

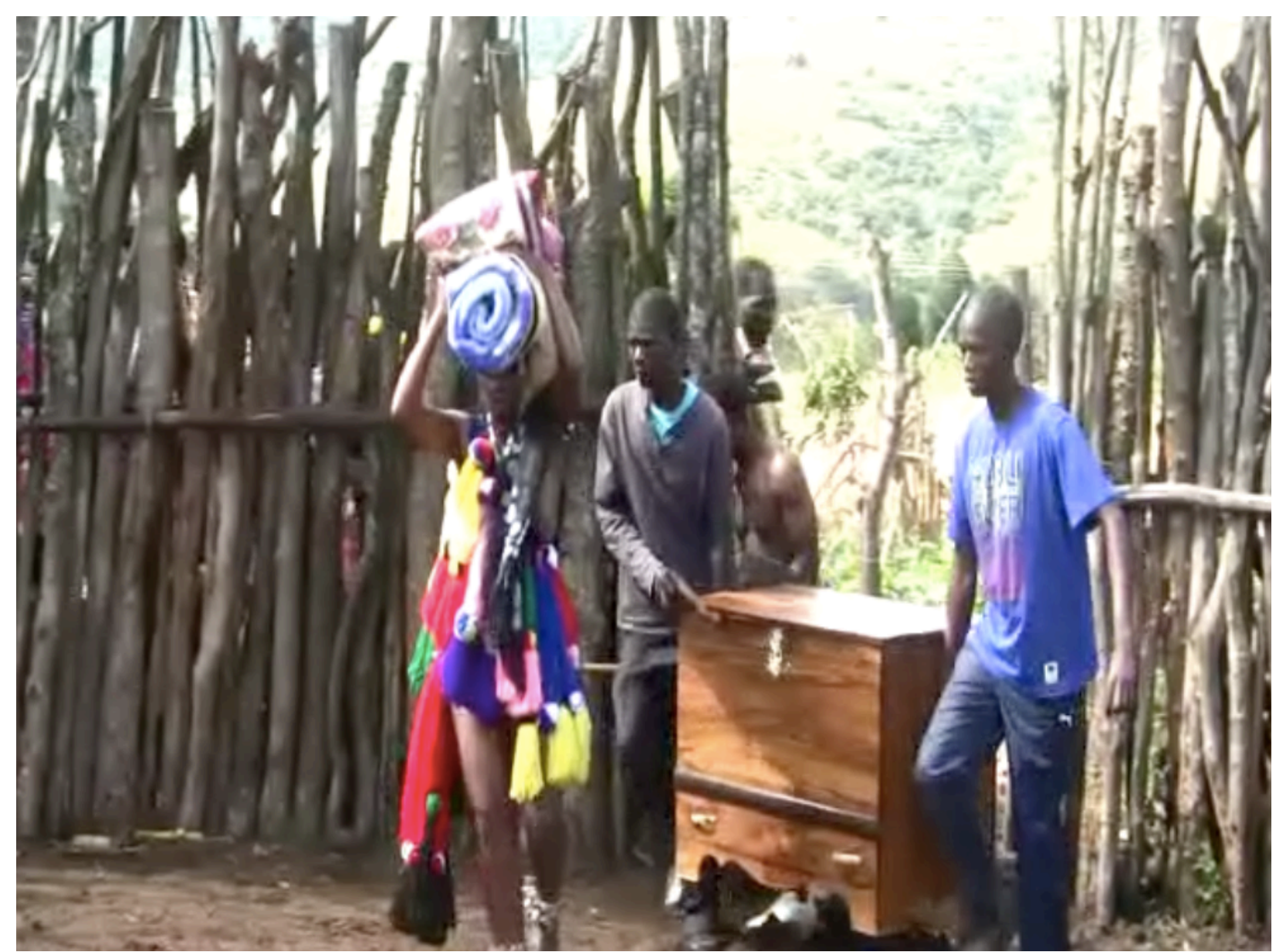

[Figure 1: umtsimba wedding, southern Swaziland 2011: Two young men carry a bride's hope

chest, following a young woman in traditional attire carrying a bundle of blankets and grass mats also belonging to the bride. The trio brings the bride's belongings into the groom's family's cattle pen, preceding her actual introduction to the family. Digital video still by C. Golomski] 
Contemporary challenges to this memory work highlight a second objective of this article: to situate current globalized religious contests surrounding clothing and other material objects as a problem for women. In this case, the global expansion of anti-ritual ideologies of Pentecostal Christianity presents a conundrum for those who undertake these rituals to achieve wellbeing. For the bereaved, manipulating clothing and material images of the deceased enables intersubjective transformation and psychosocial transitions. Simultaneously, these actions evince an ethical imagination that is global in scale. Namely, while the bereaved empirically remain local, their memorial practices are inspired by and negotiated through imaginings of the global and engender moralized social relations between the living and dead through materiality.

In this article, I first describe standard public circulations of clothing in funerals and their purification. I unpack local concepts of clothing as object and action for memory and how these dynamics reveal notions of permeable, intersubjective personhood. Clothing and materialized images operate as sikhumbuto, "a thing that causes remembrance," effectively a reconstitution of a deceased person. I present three cases of women's use of clothing objects and their global dimensions, and finally discuss how women push back against the anti-ritual stipulations of Pentecostalism. Distance between the bereaved and dead at the time of death and afterward reveal the utility of clothing in restoring tangible, sensorial intersubjectivities. In this sense, clothing becomes a powerful form of embodied materiality. It is a material form that renders potential emotional, if not moral experiences, and "is supported by cultural concepts of the person that make people 'present' to each other in particular ways" (Parish 2014: 33).

Theoretically, Langford (2009), Robbins (2013), and others point to ways that the global and its articulations present challenges to peoples' sense of local centrality and their relations with the dead and transcendent phenomena. This article considers how material forms as clothing 
engender intersubjective relations with these alter persons and entities, as well as their reconstitution at local-global interfaces which are simultaneously material, virtual, and existential (Chu 2010, Bernal 2013, Jackson 2013). In this sense, clothing is polyvalent, in that its multiple meanings derive from "intellectualized reflection, inarticulate embodiment and subjective experience," and "postcolonial relations of domination and struggles with foreign hegemonies" (Durham 1999: 390). Extending from these claims, this article theorizes clothing at the intersections of memory and the global by accounting for the ways its materiality can also “expand the limits of a particular gendered domain" of practice (Hoskins 2007:111). Namely, the practices of bereaved women in this small corner in Africa involve a tangible, emotional "wearing of memories" that enable psychosocial transition, the formation of intersubjectivities, and counter global stipulations about clothing's use.

\section{CLOTHING, DEATH, AND MEMORY}

Clothing in Swaziland both action and object. To wear customary clothing is kuvunula, and customary attire itself is imvunulo. Collectively, everyday attire is timphahla or tingubo, and "to wear" these types is kumbatsa or kugcoka. Clothing variably means to drape, cover, blanket, or adorn oneself or another in these different forms, referring to articles like pants, shirts, skirts, blankets and even grass mats, which are exchanged across generations and families at life cycle rites. As clothing relates to death, the elaboration of widows' mourning rituals (Klaits 2005, Potash 1986) and the relation between cloth and mortuary rites is well documented (Weiner and Schneider 1989, Addo 2013). In Swaziland, while there is considerable debate in Christian churches, nongovernmental organizations (NGOs), and national legislation surrounding the 
status of widows and the compulsion to wear mourning gowns, less has been said about the clothing left behind by the deceased, its value, and what it means for the bereaved. Women, rather than men, bear the brunt of public mourning rites and attire.

Many people explained what happens to the deceased's clothing through a general discussion of funerary procedures. Before the burial, women collect and ceremoniously process the deceased's clothes at the night vigil and burial before some articles are also interred. ${ }^{3}$ One informant, a grandmother with a Master of Family Science degree described:

"They will take all the clothes and they put it in a big sheet. Then maybe the sister or a female relative takes the sheet full of clothes and there at the grave she will bring the load and sort of show the dead person the clothes and then take them away. They will then keep the clothes and put them inside in the corner in the mourning house."

Keeping clothes in this way echoes Hilda Kuper's (1980[1947]: 183) colonial-era description of "a small fender where heirlooms and offerings to the deceased are placed" in the main wife's house after a man's burial. The mention of heirlooms indicates memorialization through personal possessions, but the grandmother and others did not elaborate on their function or on the meaning of interring the dead with their clothes. In another interview, I asked two members of a church burial cooperative about its interment who said,

"We just put in a few clothes in the grave when we bury the person. I don't know why we do that. I think it's for when they will rise up again. Don't you put the clothes on the dead in America, or do you just put them naked in the ground? We dress them, but we don't put a lot of clothes in the grave. There are only one or two pieces. Okay, we dress the person nicely 
and then put that one piece of clothing on top. We put it on top [of the casket], maybe because they will be cold, so we cover the box with it. It is just a Swazi custom, I think.

At the twenty-plus funerals I attended between 2008 and 2014 the deceased was always dressed in very nice clothes. If the deceased belonged to a burial cooperative or had a funeral insurance policy, mortuary employees would prepare and dress the person in clothes brought by the deceased's family. I never observed the placement of extra clothing with the deceased inside the casket, nor did I view a presentation of the clothes to the deceased and their revocation as described by Bonisiwe. The more common sight was of clothing placed on top of the casket. Usually, a woman leads the funerary procession at the morning burial, carrying a rolled-up grass mat and blankets on her head to place in the grave after the casket was lowered inside. ${ }^{4}$ These represent the deceased's possessions, which would also effectively clothe or cover the body. 


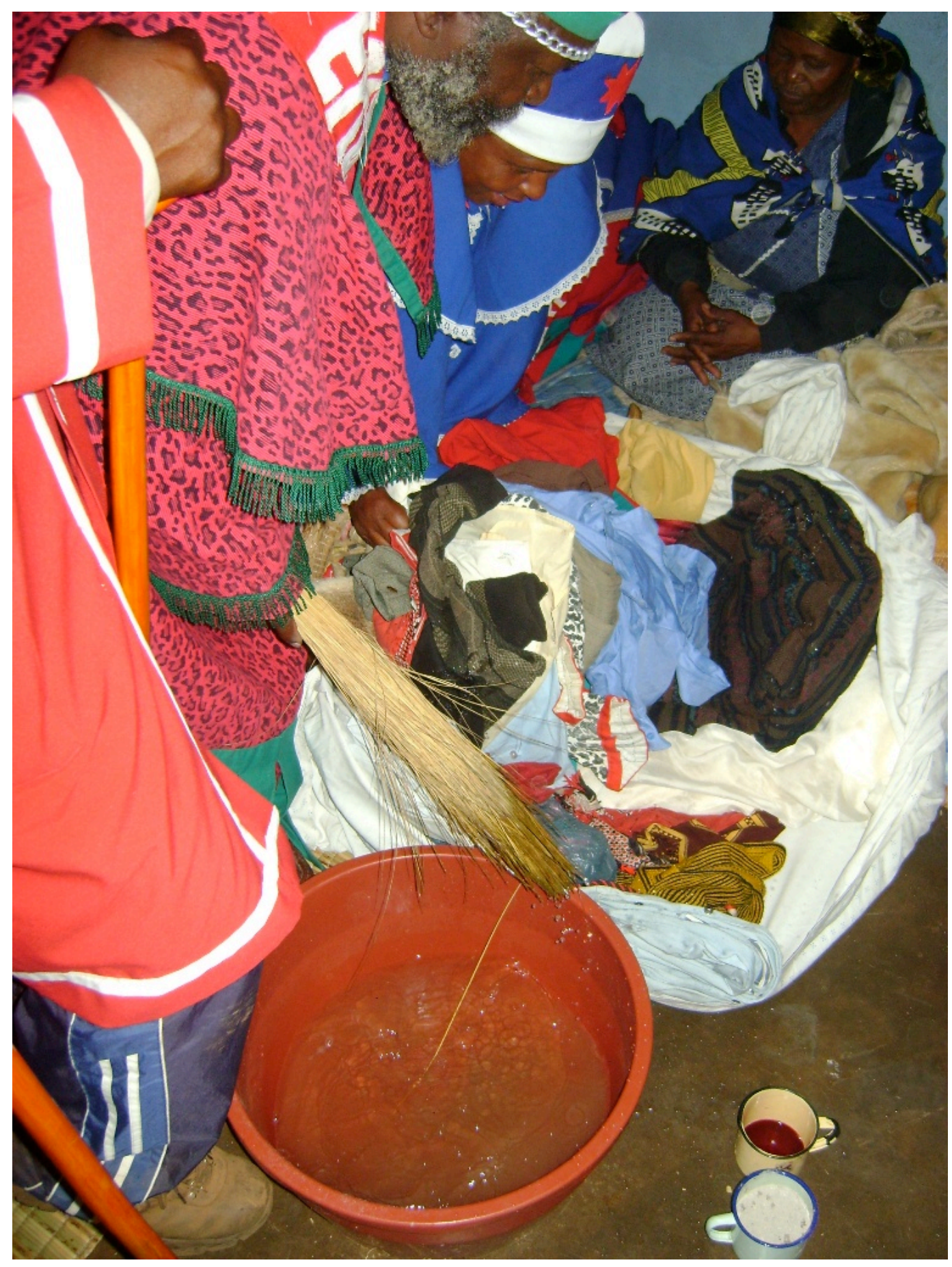

[Figure 2: purification rite, southern Swaziland, 2008: The widow of a Zionist pastor looks on as a church member holds out a sheet of clothes formerly worn by the deceased husband while his colleague, another pastor, cleanses them with a blessed mixture of water, salt, cow's blood, and ashes. Digital photograph by C. Golomski] 
The clothing remains at the deceased's natal or, for a woman, marital homestead with the principal mourners until both they and the articles of clothing are "washed" at a purification ceremony about a month later. This may include a literal washing of the deceased's clothes and mourners' bodies, as is done in Christian spirit churches with blessed mixtures of water, salt, ash and cattle blood. Close female relatives distribute the clothing and have discretion as to whom they are given. Despite the norms of generational and familial exchanges of grass mats and personal goods at marital rites, people were unable to identify a logic for this clothing's distribution. "By giving the clothes to others, when I see [the clothes] I will remember [the deceased]," explained Bonisiwe. While the public exchange of material goods in other rites speaks to a reproduction of personhood across the life course, women's circulation of the deceased's clothing evinced a more private dynamic enacted through idioms of memory.

"To remember" is also "to miss" or long for, kukhumbula, and the symbolic or material form that manifests memory is sikhumbuto (plural, tikhumbuto.) Tikhumbuto can also be trophies and medals from youth sports competitions, family photographs, hand-made objects like children's art, and other objects that festoon peoples' homes. People themselves may also be sikhumbuto, namely kin who resemble someone else in name or phenotype. In recounting the passing of her sister, one woman, Msizi, explained that her sister's daughter is a sikhumbuto of the deceased sister as the daughter's face looks like her mother's. Sikhumbuzo, the isiZulu equivalent, is a popular boy's name in siSwati and isiZulu, referring to a child who reminds others of a family member or appears as an incarnate human gift from ancestors.

The potency of clothing also traces to cultural conceptions of ontology and permeabilities of human bodies and material things. ${ }^{5}$ Historically in Swaziland, a significant association pertains between bodily persons and things, mediated by the vitality of each. In describing 
customary diviners, Kuper (1980[1947]:161-162) noted, "the power of ritual lies in the owner as well as the objects he uses" and "the more serious the situation [the specialist must deal with, like affliction], the more obvious this becomes." Her informant explained,

"Everything... goes by connection with people. If a potteress fires a pot during menstruation it will crack. A human body is more than flesh and bone and blood. It has the spirit that joins with things the body touches... [Things] must unite with the power of the person who applies them."

Also, in local Zionist and Apostolic churches, the body's power elides with clothing as where worshippers' garments are animated by ritual actions of running and dancing to induce healing and possession. In these ways, clothing objects are uniquely qualified to figure and control representations or images of other persons. Clothing literally figures a person, outlining shape and size, stretching, tearing and wearing to the contours of physical form, but can also retain polluting elements of the person as well. The transfer of affect and substance shores up the power of proximity inherent in clothing and bodies it adorns.

The following cases show how this dynamic engenders memories. The deceased's personhood could materialize as memories for the bereaved through manipulation and distribution of his or her clothing. The living assuaged grievous experiences through this ritual manipulation of clothing objects, and their explanations of its use foreclosed multiple circulations across ontological and national borders.

\section{A CHILD: THE WHIZ KID}


On New Year's Eve I drove Msizi to visit home-economics teacher Nomonde Mabuza. We stopped at a grocery store to buy cooking oil, bread, frozen chicken portions, garlic, and other sundries as comforting offerings. Msizi and Nomonde knew each other because of shared travel trajectories to the US: both their sons had recently studied in New England. It had been a little more than one month since Nomonde was told that her son Kabelo Zwane, the "whiz-kid" as named by local newspapers (Nxumalo 2009, Masuku 2009), suddenly passed away.

She welcomed us into her small flat, thankfully received the food, accommodated us with refreshments, and began to tell us about her son's school successes, travels, and the series of events involving his passing. Before that, she went to another room and came back with several items. First was Kabelo's pencil-drawn self-portrait. Then, there were copies of his national ID cards and photographs from his graduation and prom. Finally, there was a pair of crisp white sneakers. "Even here is his t-shirt," she said holding the ends of the black t-shirt she wore, stretching it out before her.

Kabelo, her first born of two children, was a talented young man who attended the prestigious Waterford Kamhlaba United World College in Mbabane for his international baccalaureate. After graduation, he made his move to the US in 2008. Kabelo applied for and became the first Swazi national to be accepted to the Massachusetts Institute of Technology (MIT) in Cambridge, MA and began a degree program in mechanical engineering that fall. At MIT, Kabelo was a member of several student groups, and his peers and advisors described him as modest, inquisitive, and kind.

Kabelo went missing from campus on October 25, 2009. On November 7 he was found dead from self-asphyxiation in a wooded area of Bedford, MA. Police were able to identify him 
by tracing the registration details of his mobile phone found in his hand. They subsequently notified the university, which then called Nomonde. He was repatriated to Swaziland on November 16, and a public memorial service followed his return. He was buried at a newly expanded cemetery in the foothills of his alma mater. Following the service, Nomonde was flown to the US for several days to meet with MIT administration, Kabelo's advisors and peers, and police. Nomonde later wrote to me in a letter:

"Whilst in Boston, I requested that I be taken to where Kabelo was found dead, and I got a statement like, "are you sure you wanna see the place," and I was like 'Yeah, I'm the biological mother. Why shouldn't I see that place?'... I so much wish I had placed wreaths at the place where he was found dead, instead of being told, 'Sorry it's a wetland area,' by the police officers."

Despite the circumstances grounding the trip, she otherwise made glowing reference to the US when we met her that New Year's. Profoundly apologetic for her loss, she said that the administration also told her she would fit well living in their "Western environment." Throughout the rest of the afternoon she made suggestive remarks to me about facilitating her return to the US.

Almost a year later to the date I visited Nomonde again at her flat. Again, she wore one of Kabelo's t-shirts, a white cotton T with a logo for an HIV/AIDS orphan NGO with whom he volunteered. We conversed about Kabelo's personal belongings. "What happened to his things at school?" I asked. "Well, he took most of his things with him when he left [Swaziland]" she told me. "Here at home he only left behind four pairs of jeans and a pair of shoes." She again presented the crisp pair of white shoes. "I like to wash these and keep them clean like the jeans," 
she said, "at MIT, there was nothing left [in his dorm room]. They gave me his laptop, but there were no clothes left in his flat when they went to check on it. He must have thrown his clothes away before he did the suicide. That is how you knew it was a suicide."

For Nomonde, immateriality was an index of suicide, one of the worst kinds of death. Without a set of material residuals, his mother was unable to mourn his person embodied in clothes that might be redistributed to others. A pair of ritually washed shoes and a few t-shirts and jeans offer Nomonde a repertoire to evince his presence through tangible instantiations of memory. Not only was the lack of more of his clothing and other goods problematic, but also her inability to visit the physical site where he passed away. While flowers and wreaths are contemporary and commodified means to memorialize the deceased at graves, ritual specialists are often asked to shake the branches of indigenous flora at the site of death, umlahlabantfu, effectively releasing the deceased person's spirit. For Nomonde, materializing her grief becomes a critical project of self-production and reestablishes connections with her son who circumvented a conventional death.

Kabelo's mother and others saw his passing as indicative of the failure by those around him, namely school administrators to care for a person alone in an unfamiliar environment. She is not unaware of other infamous MIT suicides and wished her son were monitored more closely, citing how immigrant students were more vulnerable without an in-country familial network. Kabelo's time abroad also constituted a potential source for life-giving material resources of social and financial capital in remittances to his family. Indeed, I helped her complete his tax returns to claim what he earned from his work-study job. In the wake of his passing, also Nomonde wanted to follow in her son's path: "These memories, eish! I have to get away from them," she told me, "It will be better if I get to leave here and go away to stay in the States." 
Visits to Swaziland by many of her son's friends from Waterford KaMhlaba and MIT fueled her wish to migrate with the potential to earn money abroad to aid her daughter's education. She eventually received a ten-year visa and got to Canada through the help of a friend.

James Ferguson (2008), following Julia Kristeva, describes an “abject” relation between Zambians and the global North, where the former are actually cast out from modernity's lofty claims of economic and cosmopolitan inclusivity. Indulging Africans in lucrative possibilities of inclusion without providing foundations to act-importantly, as Nomonde and others understood it, to care for youth like Kabelo_-is disingenuous on the part of the global North. Nomonde's successful migration, however, represents a reversal of this conceptually unidirectional global flow. While humanitarian and development organizations of North flow toward Africa and the global South in efforts to transform actions of care for bodies and communities, Nomonde's movement forces questions of how the North could not rightly care for her son in its own spaces and terms. His passing, registered in the immateriality of missing clothing and closed off flows of remittances, was rerouted in his mother's passage to the North, thereby reopening flows of resources for her daughter. The manipulation of his remaining clothes both refigures his personhood as memory and discloses multiple attempts to transcend emotional, interpersonal, and transnational borders.

\section{A LOVER: NOZIPHO’S DREAMS}

Nozipho is in her early twenties, and like some of her peers also adopts a unique name like Star or Zee Krystal. The daughter of a doctor, she was encouraged to try Sebenta, a technical college but skirted her guardians' wishes to live a wilder lifestyle. Her dream job, she told me, 
would be for a "backpackers," a hostel usually owned by expatriates catering to Northern tourists. "The clothes [the backpackers' workers] get are so awesome. I would love to go around in the jackets, shirts and things you wear when you work there. I just don't know if they are hiring," she said. Like elsewhere globally, clothes indicating one's place of employment, church membership, or participation in global health and development organizations like Kabelo's HIV/AIDS NGO become popular forms of self-expression.

Usually when I met Nozipho, she would be discussing the aggravations and pleasures of romantic relationships over dagga (marijuana) cigarettes and bottles of beer with friends. She lives alone in a small pink-painted house, a newly built three-room structure that stands out from her neighbors' impromptu stick-and-mud houses and one-room concrete rental units. Nozipho secured this place through a romantic relationship with a suitor 35 years her senior, a Dutch man she met at a party for expatriate airplane enthusiasts. The man has since provided her with both affection and goods, like her house. The man is also reportedly HIV positive. One of Nozipho's friends revealed this to me as we went around the neighborhood conducting surveys, telling me wryly, "we don't know if she is [HIV] positive too." This friend also dates expatriate men and receives goods like diapers for her children and electricity payments.

While maintaining her relationship with the Dutch man, Nozipho was also involved with a boyfriend named Sugar. Like Nozipho, Sugar liked to party, and the two got along infamously. The two had been involved off and on for over five years. Sugar passed away suddenly in September 2010. "He passed from BP (high blood pressure). He got sick, and after four days, he went just like that," she later explained. Sugar's mother put an obituary in the Times of Swaziland newspaper and had the means for a funeral through an insurance policy. The funeral was held at his mother's household in KaKhoza, an urban neighborhood similar to Nozipho's. 
The night of the vigil, her friend asked me to come: "she needs more people on her side here." Having more attendees accompanying a friend of the deceased would shore up attempts to publically affirm their romantic relationship as socially meaningful.

I did not see Nozipho until a month after the funeral. She later told me she stayed in her house to "think about other things," but simultaneously warned me that being alone with one's thoughts and doing nothing is dangerous that lands people in the state psychiatric hospital. After picking her up in town and riding to her flat to visit for the afternoon, I asked her how she was getting along. "Good," she said, "very good!" I asked her whether or not she had kept any of his things, using the word timphahla, connoting a wide range of household items including clothing. "Here!" she laughed. Yanking up her zippered fleece jacket and a white t-shirt with one hand, she exposed a baggy black shirt with the other. It was noticeably larger than her small frame. I laughed along with her as she told me it was Sugar's. "It reminds you of them," she explained, "I like to wear this shirt when I go to sleep in bed at night. You see, maybe I will dream about him."

Nozipho spoke to a cultural convention that dreams are potent windows to contact the deceased. Because they used to sleep together, the t-shirt evinced more sensual memories. She asked his family for the shirt, and they obliged to give it to her after the funeral, as well as a fine aviator jacket. She felt lucky, as she was not family and felt less likely to receive such goods. Girlfriends or unmarried female lovers, even if they are mothers of deceased men's children, are often excluded by closer kin from participating in more public and formulaic rites at funerals, if not made the butt of jokes and criticism (Dlamini 2006). Nozipho's five-year commitment to Sugar, however, was enough to persuade his mother to release a few pieces, enabling her to memorialize her boyfriend as sikhumbuto and constitute enduring intimate contact across realms. 
The materiality of this relationship extends beyond his life, and in Nozipho's case, enlivens his memory in her personal ritual practice. Of course, the visitation of the deceased in dreams is a common across cultures (Mittermaier 2011, Hollan 2013), and formerly for Swazi, carved wooden headrests, ticamelo, both kept the head elevated to protect indigenous hairstyles and provided a dream portal for ancestral contact. Contact between the living and the dead, or the enactment of an image of the dead in the dreamer's mind, is especially enabled by material forms that emanate and embody the deceased people like Sugar as memory.

The manipulation of clothing and the images of the deceased it portends recall Michel Foucault's (1986) elaboration of Ludwig Binswanger's treatise on dreams. The dream as imaginative experience reveals not only both one's subjective and objective existences, but also human freedom in one's perceptual movement between the two. In this movement, one "discovers the decisive point of bifurcation between those images in which [existence] becomes alienated in a pathological subjectivity"- a pathology recognized as therapeutic in some Swazi and Western psychologies of mourning (Lovell, Hemmings \& Hill 1993)—“and expressions in which it fulfills itself in an objective history" (Foucault and Binswanger 1986:74-75). What though is this "objective history" for contemporary Swaziland and where are Nozipho's actions in this field?

As part of a broader argument about romantic love in Africa and its global circulation, Jennifer Cole (2009) details how Malagasy youth often forge multiple, sometimes collusive relationships across social, ethnic, and transnational borders to satisfy conventions of material exchange and desires for personal affection. Cole shows how young women seek out expatriate men to fulfill material needs and wants, alongside a younger Malagasy man, a joambilo, who offers romantic fulfillment. Nozipho similarly forges a lucrative yet potentially dangerous 
relationship with the Dutch man to secure material wellbeing while also seeking out youthful relationships with Sugar, a young Swazi man. Material exchange through commercial consumption is an important factor in maintaining romantic closeness in neoliberal economies (Padilla et al. 2007, Cole 2009). Many youth described to me the new importance of gift giving through a socio-emotional concept called "tender care" or "TC," and the growth of Hallmarktype shops in Swaziland, selling trinkets, cards and other objects as tender care have further materialized romantic love. In this way, Nozipho’s indulgence in the image of Sugar as sikhumbuto through his clothes points to her mourning and the making of a materially-animated intersubjectivity, as well as her position in "objective history" as a youth in contemporary Africa inspired by globalized notions of romantic love and their material traces.

\section{A MOTHER: LARGE SKIRTS}

Tengetile is a bible college instructor and pastor's wife. Her brother is a prolific Pentecostal pastor often called by King Mswati III to advise on interdenominational religious issues. Tengetile forms part of the nation's theological intelligentsia, providing moral guidance to church leaders, lay brethren, and bible college students, and has traveled with government envoys as a spiritual adviser. She has authored several religious studies textbooks that are used at secondary and post-secondary levels. Her positions have become more authoritative accounts of religion in the national curriculum and are sources for Swazis to first critically engage the intersections of Christianity, world religions, and Swazi traditional religion. I often sought her advice on navigating local bureaucracies and her insights on religious life broadly. 
I visited Tengetile at her office one evening in November 2010. A few rays of the lowlying sun came through the window blinds, spreading across piles of exam papers. That semester, a colleague who regularly taught courses on African traditional religion was on leave, and she was covering this degree requirement. She explained:

"In this class, we are now talking about worldviews and whether or not worldviews can change. I see that they do not change, but rather they become reoriented... When you encounter a different worldview than the one you are living with, you reorient yourself rather than change everything completely. Our world is full of spirits! If I hit my toe on the door, it's not my own fault; something did that to me! The thing now is that we do not worship them or talk to them so much."

For her, like many people globally, spirits exist. They are ontological facts and affect human lives in material ways, even if some overriding secular or other Christian worldviews say otherwise. "So although we may re-orient our worldview based on what we come to learn and know, we still inhabit the same lifeworld with others before," I suggested. "Eh heh," she agreed. Speaking more about worldview reorientation through the example of her own Protestant mainline church, she noted their decision to review their church's practices to assess themselves in relation to currently popular Pentecostal worship trends and churches coming in from Nigeria, South Africa and the US. Such included men like TB Joshua, TD Jakes, and Creflo Dollar, and acts like the laying of hands and speaking in tongues. Tengetile's church did not promote these men outright or undertake these "persuasively aesthetic" acts (Meyer 2010), but being a leading, critical scholar of religion, she was aware of her congregants' perception and potential uptake of these emergent forms. 
We talked about a memorial service for a primary school teacher we attended at her church two weeks earlier. Four buses of students had trundled in at lunchtime for songs and eulogies. The teacher's funeral took place the following evening and this memorial service was mostly for his students. Tengetile noted that many of her congregants were concerned, following remarks by her pastor brother at the following Sunday service that memorial services and presentation of the body dangerously paralleled customary rites of ancestor veneration. The intersection of memory, materiality and ritual led us to a discussion of sikhumbuto.

Tengetile explained the standard funeral and mourning rites involving clothing before turning to her own redistribution and possession of the deceased's clothing. Her case involved her mother's passing and funeral, and her experience compelled her to ritualize the garments she retained:

"They called me to come after some time from the funeral, and I was to take the clothes and go through them all and give them to friends and others I thought should have them. By giving the clothes to those people, when I see them I will remember [the deceased]. It was something that meant something to me. You know, from my mother I took two or three skirts. I keep them and when I wear them I can remember her. You know, she was a big woman, but I even took the skirts to the tailor who remade them for me. Now I might wear them and think of her. It is not this ancestor worship thing. You are remembering."

Her narration about the skirts was amusing to us, as Tengetile is slim. In manipulating large skirts, her mother becomes tangibly deployed as memories within her respective social networks, manifesting her presence when friends and relatives gazed on her familiar clothes. The manipulation of the garments does not invalidate or make inauthentic the figure of the mother, 
but instead serves as a sikhumbuto in potentia for Tengetile to engage at her discretion. Here, the work of memorialization not only involves the principal actor with personal aims to remember the deceased in material form, but also a craft specialist, the tailor, to make material forms practical for the actor's aims. Re-sewn and stitched, clothing and the deceased are made available for the living as memories. The agency of the living predominates, as the dead do not compel the living to reassess their actions to receive beneficence as they would in an ancestral veneration complex.

In her explanation, ancestor worship is understood to be a similar material process and hearkens to the cache of objects Kuper described in the household "fender," although they are differently animated in actions of worship versus memorialization. In the latter, the deceased are conjured as memory, a conceptual and ontological presence with whom the living interact on their own terms rather than on the terms or sociality of the dead (Langford 2009). "They are alive in your memories," Tengetile explained, a possessive, strategic enactment by the living in ritual action through clothing. In a plural Christian religious context and amid the rise of Pentecostal Christianity, however, this spiritual-material entanglement has become evermore fraught and gets traced out in subjective reflection as Tengetile did.

To summarize the cases, for Nomonde there had been a disproportionate loss of clothing associated with the deceased, her son. The evacuation of clothing indicated the evacuation of his person from future circuits of grief work. Without a load to remember him by, the bereaved were not able to fully constitute his memory as well as their own personhood as bereaved. Suggestively, because of the lack of clothing items available for use or redistribution, Nomonde evidenced more obsessive manipulation of the remaining items. The global dimensions of the case guaranteed that narratives of Kabelo would circulate in popular conversation across nations, 
but the fact that the death was a suicide, and one without material remainders, made it inauspicious and registered ethical revaluations between persons and nations.

Nozipho conjured sensual memories of her deceased lover through articles of clothing she secured after his funeral. Participating in the funeral and displaying her commitment to the deceased, she was given affective objects that engendered his presence. For Nozipho, the use of clothing is also a form of self-expression, indicating her personal, occupational and affective aspirations and her social position as a contemporary youth participating in commercialized material exchanges. Her relationships represent newer and multiple globalized ideas about romance, and involve both global and local actors like the Dutch man. These exchanges traffic between multiple domains like the living and the dead in altered states of consciousness in dreams and across social, ethnic, and transnational lines in romantic consummation.

Finally, Tengetile's manipulation of her mother's clothing and her justification of the action traverses the personal and the theological. She is an arbiter of religious knowledge and practice, straddling lines that are sacred in her church and secular in workplace of higher education. She traffics in critical global perspectives on religious ritual, but must uphold a standard set of principles for her Protestant, non-Pentecostal church. She further expands the scope of memorialization to the global by situating her actions in Western psychologistic terminology, which turns out to be a medium of negotiation for retaining such material practices in the face of variant global critiques. The image of the deceased, materialized as memory in clothing and in the body itself at funerals, is what the bereaved justified in the midst of changing and popular religious discourse, a discussion I turn to next. 


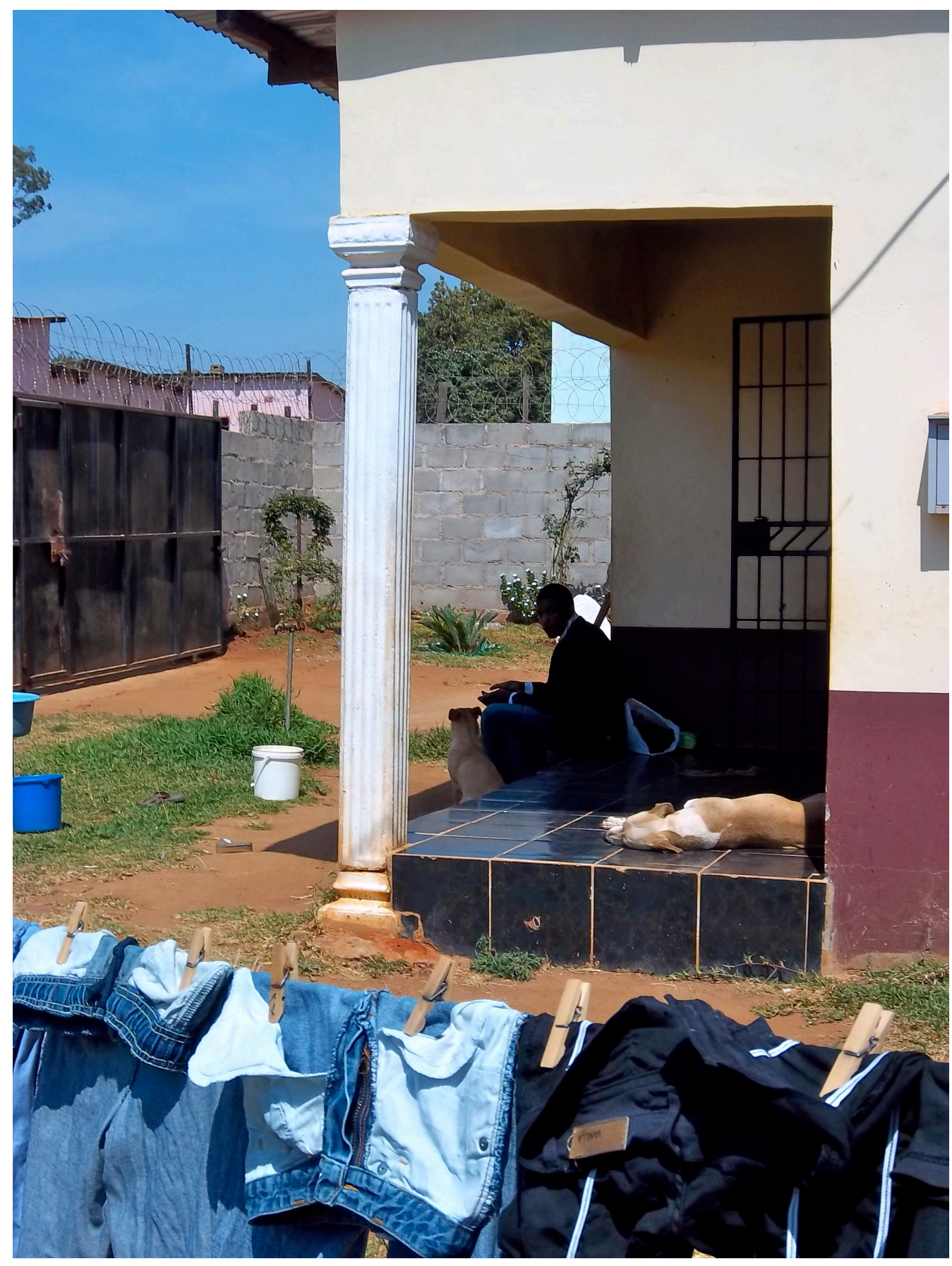

[Figure 3: Sunday washing, central Swaziland, 2010. A young man sits while visiting his cousin's house after church. The cousin's children's clothes dry on the line. Digital photograph by C. Golomski] 


\section{THE GLOBAL AND THE IM-MATERIAL}

In the following weeks, I attended a bible study session at Tengetile's church, which encapsulated the wider global contests over ritual, memory, and materiality currently taking place in Swazi Christian churches and society. Like elsewhere across the global South, Swaziland witnessed a proliferation of Pentecostal-inspired churches, locally defined as “ministries,” springing up amongst local spirit churches and long-standing, mission-derived mainline Christian churches in the late 1990s according to laypeople, pastors, and representatives of national ecumenical bodies. Many attribute Pentecostalism's rise to an influx of visiting pastors and televangelism from the US and Nigeria like TD Jakes and TB Joshua, an assemblage that points to a transnational, coherent religious discourse involving images, rhetoric, and media (Meyer 2010, Eisenlohr 2011). As many Swazi fans of religious media I knew understood it, there is a global community of believers who have been born-again and incorporated into a shared Christian world and worldview. The worldview is grounded in, amongst other tenets, a mission of anti-materialism or -ritual, including forms of adornment, even as Pentecostalism employs its own persuasive material aesthetic forms and practices. Personal religious transformation requires an often-difficult reflexive turn and renunciation of familiar customary forms, instilling ambivalence for those struggling to reconcile subjective experiences towards the deceased with commitments to globalized Christian fellowship.

These discourses are taken up locally, like for Reverend Grace Masilela, a former traditional healer turned Christian leader who staked the question in The Swazi Gospel Sun newspaper, "are mourning gowns for Christians?" The answer: (Christian) women are not bound to do so if they are compelled by their in-laws following husbands' deaths (Mngomezulu 2010, Sukati 2009). A life insurance broker told me once, "as Christians... we no longer mourn that 
way. We mourn with our hearts," explaining how his family would never sacrifice cattle at a funeral nor make women wear mourning gowns. The supposed value of immaterial remembrance is that it is marked by interiorized, unnoticeable practice, a common theme that emerged in sermons and testimonies at Pentecostal worship services and funerals. Material objects including clothing and the deceased body itself were supposedly vehicles for dark powers to overtake the bereaved who were already considered to be ill in their emotional state. One of my research assistants, Gcebsile, explained to me that some people believed certain objects like “clothes, necklaces, earrings and especially pastors' suits” were means for metaphorical demons to latch onto our lives. Attempts to live a Pentecostal-inspired life were threatened by unethical material indulgences.

From sermons and bible studies one learned that the body is the least valuable in the tripartite of body, soul and spirit, its very vulnerability to injury and decay juxtaposed to the eternality of the latter two. Because God is a spiritual entity, the facets of soul and spirit are congruous to God in immaterial form and elevated in value. Preservation and continuation of the spirit was upheld, and bodily remains should be forgotten, as they would rot away and cause pain and terror. The deceased body experienced nothing, so showing sympathy for the its physical and emotional state was said by some Pentecostal pastors to be foolish.

Given these stipulations, some Christians' rituals involving the deceased's clothing and his or her image were also said by some pastors to be transgressive. A bible study session at Tengetile's church, however, showed women's hesitancy to conform their ritual actions to global Pentecostalism's anti-materialism, as well as their agentive insertion of their actions into Western psychological rhetorics of mourning. It also shows women's roles in the social reproduction of personhood for both themselves as bereaved and for the deceased as a memory. 
Tengetile's mainline, mission-derived Protestant church holds bible study each Sunday. While the leading pastor, her brother, generally did not usually invoke the worship styles of Pentecostalism—like speaking in tongues and laying hands—-he had been recently critical of certain customary practices or saw evidence of them in the church currently, as with the teacher's memorial service. One Sunday, he handed out a 15-page packet titled "Dark Mortuary Customs" at the bible study and opened by noting how Africans believed that misfortune is a legitimate cause of death, in contrast to rational understandings of natural deaths. The body turns to dust and cannot return as an animated corpse, and the spirit ascends to heaven, he explained, citing New Testament scripture as justification and opened up for others to speak about potentially dangerous customs they knew.

Clothing was the first topic of discussion. "Sometimes they say that if person in the [casket] is wearing buttons the person will come back as a ghost," a woman suggested. The pastor agreed and elaborated further by deriding emotion and shoring up thrift:

"Let us not waste resources. When a person dies, the mothers take the clothes, panties and underwears and they put the whole overflowing load of the clothes on [the deceased]. They will be carrying all those things to the grave. So even when they are lowering down the casket into the ground, they are throwing all the clothes and panties into the grave too! The dead person is going to have all those panties then on the other side! These are the ones who are said to be children of God!”

The pastor made dramatic squeals, imitating a woman in anguish at the funeral. A few congregants laughed at his performance, but it was obvious that most felt some discomfort, and several began to justify their desires for an image of the deceased in the funeral and afterwards, an image rendered not only in clothes but the deceased's material presence as a body. The forum 
of the bible study session enabled a critical discussion, and as topics of rituals and funerals elided with participants' own experiences, the pastor was put on the defensive.

He turned topically from clothing to the deceased as corpse, focusing on night vigil rites where attendees approach and view the deceased in the casket before it was shut and draped with blankets, grass-mats and flowers. The pastor challenged us to justify these actions: "They have a whole thing now at the funeral where they call for the children [of the deceased] who will view the corpse one last time... saying, 'we will ask the children to come forth to pour the soil.' All of them! Then the children arrive, 'eeeee!'” he squealed, again imitating anguished women. "Why are we exposed to this thing at the very last moment? Why can't you remain with a beautiful picture of your mother or father or cousin instead of one that is inside the box?" he asked. "Just to see them all! Hey, as if you really need to see that he died?" This time, the attendees grumbled. Tengetile was the first to answer:

"When the deceased is gone, it is now you alone with your thoughts. So having seen the body, it helps you with those thoughts. I want to tell you all an example, when I lost my child, my mother forced me to go and see him. I didn't believe it happened, I was just scared to see him, but my mother showed him at the box. And after that, seeing that he was dead, because she forced me to see, those thoughts somehow left. I said, "my God, how, how, how did it happen," but it was because I saw him. It helped me during that process to know what position he was in when he was buried. So, it is part of the healing process."

For Tengetile, witnessing the body of her child permitted acknowledgement of death and activated a process of personal, psychological healing, thus transcending disbelief. Disbelief was insular; the truth of death was a fearful prospect, but the body as material evidence disclosed this 
truth. Another congregant agreed with Tengetile, and gave an example of how refusing to see the deceased had dramatic consequences:

"[Seeing the deceased] is able to heal you... for example, someone may die, let's say

tragically... like an accident, maybe you did not get a chance to see that person before he or she died and was buried. You don't really know what happened without seeing the deceased, so you will keep well by seeing for yourself. My grandmother could not believe it when my mother died. The burial ceremony had to happen, but my grandmother was still in disbelief during the ceremony and never saw her daughter when she was buried. Now sometimes my grandmother asks us how she was buried on that day. She fails to picture the death of her children from the onset. She wears those thoughts, not knowing how her child was buried." In this congregant's case, the grandmother's refusal to see the body was detrimental and circumvented her personal process of grief work, insofar that she now relies on others' memories of the deceased at the funeral. It is telling that she said her grandmother "wears" these thoughts, as if they were mourning gowns that could never be taken off because of an absent image or memory. Even if the death was tragic, as another women then narrated, an image of the deceased was felt to be necessary:

"Death comes in different forms. I lost a child. When it happened, it was tragic. I went, and when I arrived I could not identify him. If he had been buried then, with that sort of picture, I would have had a problem. But at the burial, after two weeks when I was forced to see him again, he was almost the same as the way I used to [see him]. I came and saw him, and it was different. My closure came then not before the funeral, and seeing his condition afterwards, that was the difference for me. God bless." 
Technologies of bodily reconstruction were instrumental for the mother and, in the ritual moment of viewing her son's body aided transition and materialized a picture for memory. Justifications for viewing the deceased to engender memories were affronts to the pastor's pejorative stance. He finally adjusted his approach, saying, "I'm not saying that we should never see the person, but I'm saying, when I [as a mourner] have seen the deceased in the box, why then does the pastor say, 'go see him children?"' The congregants did not take his back-tracking lightly, and they grumbled again, one woman yelping, "this is not an issue!"

Being less than successful in drumming up collective criticism, the pastor turned his energies to other topics. The attendees felt it was important to have interaction with the body and clothing to instantiate a memory at the funeral. Withholding rites was seen as short-circuiting bereavement processes. Despite popular globalized Pentecostalism, materiality and its manipulation remained potent as means to engender forms of memory for wellbeing. Interaction with the deceased, especially viewing material remains, was understood as socially customary, performatively dramatic, and mentally necessary, couched in Western psychologistic terms like "process," "healing" and "closure," and the singular intersubjective experience of grief.

Although cultural ontologies of Pentecostalism posit the consumption and performative enactment of materiality as problematic, other Christian faiths elide with humanitarian, psychological responses HIV/AIDS. For example, theologian Philippe Denis pushes for the efficacy of "memory boxes" in facilitating status disclosure and assuaging bereavement for families and HIV/AIDS orphans (Denis and Makiwane 2003, Denis 2005), arguing that such psychosocial practices are also congruent with customary bereavement rites. Such practices may also be ethical in liberating the bereaved from the moral stipulations of Pentecostal or other 
religious discourses. A perfected final image of the deceased as a whole bodily person enabled wellbeing and memory, aided by the distribution and possession of clothing and other forms.

\section{CONCLUSION}

This article aimed to illustrate the continued life of deceased persons as they were refigured in their own clothing for the bereaved. Bereavement is a difficult path, and individuated work involving clothing in Swaziland, probably much like elsewhere the worldwide, discloses both the initial experiences of loss and the potential reemergence of the deceased as materialized memory, sikhumbuto. Clothing's materiality is a potent quality registering the deceased's presence, making clothing objects and actions efficacious in cultural theories of personhood and ontology. Despite competing anti-materialist religious ideologies, sourced from a world outside Swaziland that some Christians nevertheless imagine themselves to be part of, clothing and deceased bodies were productive for women's reworkings of intersubjectivity. Their actions were both constrained and mediated by global relations and imaginaries.

Insofar as customary clothing, imvunulo, indexed social classification in Swaziland, Kuper (1973:365) stated the "importance of clothing [is that it is] a means of relating individuals to one another... Clothing is one means of notifying individuals in the social system of their respective roles and positions." Within this ideational system, however, are intimate spaces for personally creative actions, as these cases demonstrate. Kuper $(1965,1984)$ points to this personal creativity in her ethnographic fiction on how people are keen to make themselves "shine," kukhanyisa in clothing by generally looking and acting nicely in appearance. To shine, to wear both fashionable customary contemporary clothing, and to be alive, upright, and moral 
are all actions that can be classed as part of related cultural domain. In these actions, to enliven oneself through clothing not only constitutes meaningful self-expression out of vanity, but is to be commensurate with ethical ideals of self-composure and being amongst and for others in the social world. In a sense, for women in Swaziland to shine through these forms of clothing is akin to the ways in which Herero women's clothing is mediated through a Bakhtinian "sparkle," one "that surrounds objects in a heteroglossic world"—-namely, religiously diverse and global_ “"and expand it to include meaning brought by embodied sensibility" and "individual consciousness" (Durham 1999: 390-391) for those who wear or use it as sikhumbuto.

Echoing Mark Padilla and colleagues (2007:x) this article aimed to question "how contemporary shifts in late modern economies and the forces of globalization influence intimate experiences," namely the materiality of memory and ritual action as pressed upon by Pentecostalism. Pieces of clothing that bind people together in Swaziland operate not only as a form of social classification, but also as an materially embodied, intersubjective process wielded to enact presence, absence and transition between self and other on multiple global scales.

Clothing thus discloses the possibilities for intersubjectivities forged between polarities of North and South, cosmopolitanism and traditionalism, morality and sin.

\section{ACKNOWLEDGEMENTS}

I'd like to thank the individuals in Swaziland who shared their personal stories and experiences with me, especially Nomonde Mabuza, and several churches' bible study session members for allowing me to listen and record their proceedings. Ellen Schattschneider and Janet McIntosh provided early support for this paper at Brandeis University, where it was awarded the Robert A. Manners Prize. Earlier versions were shared at the Northeast Workshop on Southern Africa and a 
joint meeting of the South African Visual Arts Historians and the Comité International d'Histoire de l'Art. Laura Ann Twagira, Arianna Huhn, Shelby Carpenter, Joseph D. Napolitano, and Daria Trentini also gave invaluable feedback. Research was made possible by funds from the Andrew W. Mellon Foundation and a Fulbright IIE fellowship.

\section{NOTES and REFERENCES}

Addo, Ping-Ann. 2013. Creating a Nation with Cloth: Women, Wealth and Tradition in the Tongan Diaspora. New York: Berghahn.

Bernal, Victoria. 2013. Diaspora, Digital Media, and Death Counts: Eritreans and the Politics of Memorialisation. African Studies 72(2): 246-264.

Chu, Julie. 2010. Cosmologies of Credit: Transnational Mobility and the Politics of Destination in China. Durham: Duke University Press.

Cole, Jennifer. 2009. Love, Money and Economies of Intimacy in Tamatave, Madagascar. In Love in Africa, ed. J. Cole and L. Thomas. Chicago: University of Chicago Press, 109134

Denis, Phillipe. 2005. Never Too Small To Remember: Memory Work and Resilience in Times of AIDS. Johannesburg: Cluster.

Denis, Phillipe and Nokhaya Makiwane. 2003. Stories of Love, Pain and Courage. Oral History 31(2): 66-74.

Durham, Deborah. 1999. The Predicament of Dress. American Ethnologist 26(2): 389-411.

Eisenlohr, Patrick. 2011. The Anthropology of Media and the Question of Ethnic and Religious Pluralism. Social Anthropology 19(1): 40-55. 
Ferguson, James. 2008. Global Disconnect: Abjection and the Aftermath of Modernism. In Readings in Modernity in Africa, ed. Peter Geschiere, Birgit Meyer and Peter Pels. Bloomington: Indiana University Press, 8-16.

Foucault, Michel and Ludwig Binswanger. 1986. Dream and Existence. F. Williams and J. Needleman, eds. Seattle: Review of Existential Psychology and Psychiatry.

Hollan, Doug. 2013. Sleeping, Dreaming, and Health in Rural Indonesia and the Urban U.S. Social Science and Medicine 79: 23-30.

Hoskins, Janet. 2007. Afterword—Gendering Religious Objects: Placing Them as Agents in Matrices of Power. Material Religion 3(1): 110-119.

Jackson, Michael D. 2013. The Wherewithal of Life: Ethics, Migration, and Questions of WellBeing. Berkeley: University of California Press.

Klaits, Frederick. 2005. The Widow in Blue: Blood and the Morality of Remembering in Botswana's Time of AIDS. Africa 75(1): 46-62.

Kuper, Hilda. N.d. Hilda Kuper Papers: Box 35, folder 10 "Religion—-traditional.” Special Collections, Charles E. Young Research Library, University of California Los Angeles. . 1947. An African Aristocracy. Reprint 1980. Oxford: Oxford University Press. . 1965. Bite of Hunger. New York: Harcourt, Brace \& World. . 1973. Costume and Identity. Comparative Studies in Society and History 15(3): 348367. . 1984. Work, Missus? Anthropology and Humanism 9(2): 15-16.

Langford, Jean. 2009. Biopolitics and Spirit Debt. Cultural Anthropology 24(4): 681-711. Lovell, Deborah, Graham Hemmings and Andrew Hill. 1993. Bereavement Reactions of Female Scots and Swazis. British Journal of Medical Psychology 66: 259-274. 
Masuku, Lunga. 2009. Whizz-kid Died Holding his Cellphone. Swazi Times November 28.

Marwick, Brian A. 1940. The Swazi. Reprint 1966. London: Frank Cass.

McIntosh, Janet. 2009. The Edge of Islam. Durham: Duke University Press.

Meyer, Birgit. 2010. Aesthetics of Persuasion. South Atlantic Quarterly 109(4): 741-763.

Mittermaier, Amira. 2011. Dreams that Matter: Egyptian Landscapes of the Imagination. Berkeley: University of California Press.

Mngomezulu, Mxolisi. 2010. Reverend Grace Masilela says... are Mourning Gowns for Christians. Swazi Gospel Sun December 2-17.

Nxumalo, Manqoba. 2009. Whiz-Kid Might Have Killed Himself. Times of Swaziland November 17.

Padilla, Mark, Jennifer Hirsch, Robert Sember, Miguel Muñoz-Laboy, and Richard Parker. 2007. Love and Globalization. Nashville: Vanderbilt University Press.

Parish, Steven. 2014. Between Persons: How Concepts of the Person Makes Moral Experience Possible. Ethos 42(1): 31-50.

Potash, Betty, ed. 1986. Widows in African Societies. Stanford: Stanford University Press.

Robbins, Joel. 2010. Is the Trans- in Transnational the Trans- in Transcendent? On Alterity and the Sacred in the Age of Globalization. In Transnational Transcendence, ed. T. Csordas. Berkeley: University of California Press, 55-71.

Sukati, Zwelihle. 2009. Pastors Slammed on Funeral Traditions. Swazi Times July 15.

Vilakati, Thembi and Thembekile Msibi. 2006. Giya Sigiye. Manzini: MacMillan Boleswa.

Weiner, Annette B. and Jane Schneider, eds. 1989. Cloth and Human Experience. Washington, D.C.: Smithsonian Institute Press. 
${ }^{2}$ Zwelethu Mthethwa. 2013. New Works. Jack Shainman Gallery, New York, NY. http://www.jackshainman.com/exhibition138.html, accessed 16 February 2015.

${ }^{3}$ Kuper (1980[1947]: 177-178) shows that the deceased's clothing, amongst other "goods" were interred with the body in the grave. Married men were buried with a "black ox skin" and women in "skin skirt and apron"; both were also buried with "personal possessions." In her original field-notes (Kuper N.d.) she describes these possessions as "private," listing spoons, dishes, blankets and clothes. Marwick (1966[1940]) notes the interment of sleeping mats, blankets, spear weaponry and clothing for deceased men.

${ }^{4}$ The national curriculum's advanced siSwati secondary school textbook explains that "in the past and today, the clothes of the deceased are washed along with the body, and a procession is led by a person carrying the clothes and head-rest of the deceased, wrapped in a grass mat, to be buried in the grave" (Vilakati and Msibi 2006:230, author's translation).

${ }^{5}$ I take ontology to be cultural presuppositions about one's existence in the world vis-à-vis ideas how that world operates through spiritual, natural, or other forces and objects (McIntosh 2009). 